\title{
Hubungan Stres Akademik dengan Kualitas Tidur Mahasiswa Keperawatan Tingkat Akhir Program Alih Jenjang
}

\author{
Esthika Ariany Maisa ${ }^{1}$, Andrial $^{2}$, Dewi Murni ${ }^{3}$, Sidaria $^{4}$ \\ 1,3,4Bagian Keperawatan Dasar, Fakultas Keperawatan, Universitas Andalas, Padang, Sumatera Barat \\ ${ }^{2}$ Fakultas Keperawatan, Universitas Andalas, Padang, Sumatera Barat \\ Correspondence email: maisathika@nrs.unand.ac.id
}

\begin{abstract}
Abstrak. Tidur merupakan kebutuhan dasar manusia. Kualitas tidur yang buruk dapat berdampak pada kesehatan dan prestasi akademik mahasiswa. Mahasiswa keperawatan tahun akhir program alih jenjang memiliki resiko kualitas tidur yang buruk dikarenakan beban tugas akademik yang cukup tinggi ditambah dengan tugas lain selain kuliah yang dapat menyita waktu istirahat mahasiswa. Salah satu faktor yang mempengaruhi kualitas tidur adalah stres, dan dikalangan mahasiswa disebut stres akademik. Tujuan dari penelitian ini adalah untuk mengetahui hubungan stres akademik dengan kualitas tidur pada mahasiswa tingkat akhir program alih jenjang. Penelitian dilakukan pada salah satu kampus di Kota Padang dengan menggunakan desain penelitian analitik korelasi dengan pendekatan cross sectional. Sampel dalam penelitian ini berjumlah 64 orang mahasiswa tingkat akhir program alih jenjang dengan teknik pengambilan sampel total sampling. Penelitian ini dilaksanakan mulai dari bulan Oktober sampai dengan November tahun 2019. Pengambilan data dilakukan dengan menggunakan instrumen penelitian Pittsburh Sleep Quality Index dan Student Academic Stress Scale. Hasil penelitian ini menunjukkan bahwa mahasiswa keperawatan tingkat akhir program alih jenjang mengalami kualitas tidur yang buruk dengan stres akademik yang cukup tinggi. Analisis korelasi memberikan bentuk pola hubungan yang linear dan positif antara stres akademik dan kualitas tidur mahasiswa keperawatan tingkat akhir program alih jenjang, dengan tingkat kekuatan korelasi sangat kuat, yang berarti semakin tinggi stres akademik mahasiswa, maka semakin buruk kualitas tidurnya. Diharapkan pada mahasiswa dapat mengelola stres akademik dengan manajemen stres dan manajemen waktu, agar tidak berdampak pada kualitas tidur mahasiswa.
\end{abstract}

Kata kunci: Kualitas Tidur; Mahasiswa Tingkat Akhir; Program Alih Jenjang; Stres Akademik

\begin{abstract}
Sleep is a basic human need. Poor sleep quality can have an impact on students' health and academic performance. Nursing students at the end of the level transfer program have the risk of poor sleep quality due to the high academic task load coupled with other assignments besides lectures that can take up student break time. One of the factors that affect the quality of sleep is stress, and among students it is called academic stress. The purpose of this study was to determine the relationship between academic stress and sleep quality in the final year students of a level transfer program. The study was conducted at one of the campuses in the city of Padang using a correlation analytic research design with a cross sectional approach. The sample in this study amounted to 64 students at the end of the level transfer program with the total sampling technique. This research was conducted from October to November 2019. Data was collected using the Pittsburh Sleep Quality Index and Student Academic Stress Scale research instruments. The results of this study indicate that nursing students at the end of the level transfer program experience poor sleep quality with high academic stress. Correlation analysis provides a linear and positive pattern of relationship between academic stress and sleep quality of nursing students at the end of a level tansfer program, with a very strong correlation strength level, which means that the higher the student's academic stress, the worse the quality of sleep.. It is expected that students can manage academic stress with stress management and time management, so as not to have an impact on the quality of student sleep.
\end{abstract}

Keywords: Academic Stress; Final-year students; Level Transfer Program; Sleep Quality

\section{PENDAHULUAN}

Tidur suatu keadaan yang berulang-ulang, perubahan status kesadaran yang terjadi selama periode tertentu. Memperoleh kualitas tidur terbaik adalah penting untuk peningkatan kesehatan yang baik dan pemulihan individu yang sakit. Jika orang memperoleh tidur yang cukup, mereka merasa tenaganya telah pulih (Potter \& Perry 2006). Kualitas tidur adalah suatu kondisi yang dijalani oleh seseorang sehingga mendapatkan kesegaran dan kebugaran saat terbangun dari tidurnya (Fenny \& Supriatmo, 2016). Kualitas tidur mencakup aspek kuantitatif tidur, seperti latensi tidur, efisiensi tidur, dan fragmentasi tidur, serta aspek yang lebih subyektif, seperti kedalaman atau ketenangan tidur (Perumal, Narasimhan \& Kramer, 2016).

Beberapa penelitian telah menemukan bahwa tidur yang tidak sehat, dengan mengurangi jam tidur, kualitas tidur tidak terpenuhi akan berdampak buruk pada kesehatan. Seperti penelitian (Nedeltcheva \& Scheer, 2014) bahwa pembatasan tidur mengubah ekspresi 117 gen dari 25 jalur yang paling diregulasi, 15 termasuk yang untuk aktivasi sel $\mathrm{B}$, produksi IL-8, dan pensinyalan NF-kB, peradangan kronis, penyakit kardiometabolik, regulasi glukosa dan tingkat sitokin inflamasi. Hasil penelitian yang dilakukan oleh (Hill et al., 2018) stres oksidatif, akumulasi neuronal dari ROS dan akan menjadi patogenesis penyakit degeneratif saraf. 
Penelitian dari (Giese et al., 2013) peningkatan stres secara negatif memengaruhi tidur dan pada gilirannya menurunkan tingkat BDNF (Brain Derived Neurotrophic Factor). Penelitian dari (Sosso, Nakamura, \& Nakamura, 2017) menunjukkan peningkatan penurunan kognitif.

Tidur memainkan peran penting dalam proses kognitif serta kesehatan fisik dan mental, kurang tidur dapat mempengaruhi kinerja akademik siswa. Banyak penelitian di Amerika Serikat, Australia, India dan negara-negara lain telah menemukan bahwa siswa dengan kualitas tidur yang buruk memiliki nilai buruk pada ujian mereka dan lebih tertekan daripada rekanrekan mereka (Almojali, Almalki, Alothman, Masuadi, \& Alaqeel, 2017). Penelitian Nilifda, Nadjmir, \& Hardisman (2016) menyebutkan bahwa terdapat hubungan kualitas tidur dengan prestasi akademik.

Hasil penelitian yang dilakukan oleh Zhang, Peters, \& Chen (2018), dari 242 mahasiswa Program Keperawatan Baccalaureate di universitas negeri. Dua pertiga dari mahasiswa keperawatan dalam penelitian ini melaporkan kualitas tidur yang buruk, yang merupakan tingkat yang lebih tinggi daripada yang dilaporkan oleh mahasiswa perguruan tinggi umum di A.S. Stres yang dirasakan memainkan peran mediasi penting dalam hubungan antara kualitas tidur dan gejala kecemasan dan depresi pada siswa keperawatan.

Penelitian Martfandika \& Rahayu (2018) didapatkan hasil dari kualitas tidur mahasiswa keperawatan dalam menyusun skripsi di Universitas 'Aisyiyah Yogyakarta adalah kualitas tidur yang baik sebanyak 22 mahasiswa $(13,8 \%)$ dan kualitas tidur yang buruk sebanyak 138 mahasiswa (86,3\%). Kualitas tidur mahasiswa keperawatan semester delapan atau mahasiswa tingkat akhir Universitas 'Aisyiyah termasuk dalam kategori sangat buruk.

Menurut penelitian Giese et al., 2013; Marks \& Landaira (2016); Hallet et al. (2017); Najafi Kalyani et al. (2017); Zhang et al., (2018), menyatakan bahwa kualitas tidur dipengaruhi oleh stres seseorang. Penelitian dari Becker et al., (2015) menganalisis penelitian yang dipublikasikan antara tahun 2005 sampai 2015. Mereka menemukan bahwa stres dapat mendukung implikasi kesehatan negatif, meningkatkan kemungkinan keterlibatan dalam perilaku berisiko, yang akan memberikan kualitas tidur yang buruk. Studi telah menggaris bawahi pentingnya mengevaluasi pengaruh stres pada proses yang berkaitan dengan fungsi tidur yang tepat, mengingat bahwa itu adalah dimensi penting dari kesehatan.

Studi lain menunjukkan bahwa stres menyebabkan banyak kesulitan tidur, seperti tidur gelisah, terbangun di tengah tidur dan bangun terlalu dini. Secara fisiologis, banyak penelitian telah menemukan bahwa tidur dan stres terkait erat dengan poros hipotalamo-hipofisisadrenal (HPA), yang dapat menjelaskan hubungan erat antara kedua faktor ini. Stres akut disertai dengan penurunan gelombang lambat dan gerakan mata cepat
(REM), dan kurang tidur, telah memberikan efek nyata pada arsitektur tidur dan ritme sirkadian (Almojali, Almalki, Alothman, Masuadi, \& Alaqeel, 2017).

Stres adalah faktor utama yang mempengaruhi mahasiswa, seringkali pada tingkat yang lebih tinggi daripada masyarakat umum. Mahasiswa menghadapi berbagai stresor seperti akademisi, masalah keuangan, hubungan, dan ketidakseimbangan kerja-belajarkeluarga. Akumulasi stres dari beberapa sumber membuat mahasiswa lebih rentan terhadap kesehatan tidur dan kesehatan, terutama ketika mereka tidak dapat mengatasi secara efektif. Selain itu, stres dapat dikaitkan dengan aspek lain dari hasil akademik dan kesehatan mahasiswa, seperti kinerja akademis yang buruk, ide bunuh diri, substansi penyalahgunaan termasuk pesta minuman keras, dan masalah terkait alkohol (Hallet, Chernaik, \& Zhang, 2017).

Stres akademik adalah jenis stres yang disebabkan karena peningkatan beban kerja kelas, status yang lebih rendah dari yang diperkirakan, harapan kelulusan, dan ketidaksepakatan yang parah dengan mentor. Stres akademik memicu persepsi individu tentang frustrasi akademik, konflik akademik, tekanan akademis, dan kecemasan akademik yang merupakan komponen stres akademik (Yikealo, Yemane, \& Karvinen, 2018). Stres akademik adalah fenomena yang tersebar luas di berbagai tahap sistem pendidikan, dan itu berdampak buruk pada kepribadian, emosi, dan kesejahteraan fisik siswa (García-Ros, Pérez-González, \& Tomás, 2018).

Mahasiswa keperawatan mengalami tingkat stres yang tinggi. Mahasiswa keperawatan memiliki sedikit waktu luang karena tuntutan belajar, dengan tugas untuk pekerjaan didaktik dan klinis. Mahasiswa keperawatan mengalami tingkat stres yang tinggi karena tuntutan akademis dan emosional yang ketat yang diberikan pada mereka. Stres itu memengaruhi pengalaman siswa saat mereka berada di sekolah dan nantinya dapat memengaruhi kehidupan dan perjalanan mereka sebagai perawat profesional (Reeve, Shumaker, Yearwood, Crowell, \& Riley, 2013).

Program alih jenjang merupakan pilihan bagi lulusan diploma yang ingin melanjutkan pendidikan ke tingkat sarjana keperawatan. Menurut (Rahmawati \& Kuntari, 2014) mahasiswa Program Sarjana Kelas Ekstensi memiliki berbagai aktivitas dalam sehari-hari seperti kuliah, tugas kuliah, diskusi kelompok, bekerja, mengurus keluarga, dan lain-lain yang sangat menyita waktu dan tenaga. Hal ini yang kemudian sedikit banyak memberikan tantangan tersendiri bagi mahasiswa program alih jenjang bila dibandingkan dengan program reguler.

Mahasiswa ekstensi yang sedang menyelesaikan skripsi tidak terlepas juga dari stres akademik, itu dibuktikan dari hasil penelitian (Marbun, Arneliwati, \& Amir, 2018) pada mahasiswa program transfer keperawatan program Studi Ilmu Keperawatan Universitas Riau dengan hasil penelitian tentang stres 
mahasiswa ekstensi yang sedang menyusun skripsi, didapatkan bahwa sebanyak 67 orang responden $(91,8 \%)$ yang diteliti memiliki stres sedang, sebanyak 3 orang responden $(4,1 \%)$ memiliki stres berat dan sebanyak 3 orang responden $(4,1 \%)$ memiliki stres ringan.

Berdasarkan studi pendahuluan dengan teknik wawancara terhadap 10 mahasiswa tingkat akhir program alih jenjang di tempat penelitian, mahasiswa mengatakan bahwa kepalanya sering pusing memikirkan perkuliahan bersamaan dengan menyusun skripsi, tugas kuliah menumpuk, sulit mencari waktu untuk bimbingan skripsi, sulit menemukan referensi untuk bahan skripsi, sering mengerjakan tugas atau skripsi hingga tengah malam, sulit untuk memulai tidur, terbangun ditengah malam kemudian melanjutkan mengerjakan skripsi, saat bangun pagi badan sering terasa pegal dan masih merasa mengantuk, bahkan salah satu mahasiswa mengatakan sampai pernah tidur hanya 2 jam karena memikirkan judul skripsi.

Berdasarkan fenomena diatas, maka penelitian ini dilakukan dengan tujuan untuk mengetahui hubungan stres akademik dengan kualitas tidur pada mahasiswa keperawatan tingkat akhir program alih jenjang.

\section{METODE}

Penelitian dilakukan di salah satu kampus di Kota Padang dengan menggunakan desain penelitian analitik korelasi dengan pendekatan cross sectional. Populasi penelitian adalah mahasiswa keperawatan program sarjana. Sampel dalam penelitian ini berjumlah 64 orang mahasiswa tingkat akhir program alih jenjang dengan teknik pengambilan sampel total sampling. Penelitian ini dilaksanakan mulai dari bulan Oktober sampai dengan November tahun 2019. Pengambilan data dilakukan dengan menggunakan instrumen penelitian Pittsburh Sleep Quality Index dan Student Academic Stress Scale. Data diolah secara komputerisasi, dilakukan uji univariat, dan analisis bivariat menggunakan uji korelasi spearman.

\section{HASIL DAN PEMBAHASAN}

Hasil penelitian ini disajikan menjadi tiga bagian, yaitu gambaran karakteristik, variabel yang diteliti, dan hubungan kedua variabel yang diteliti.

\section{Karakteristik Mahasiswa Keperawatan Tingkat Akhir Program Alih Jenjang}

Tabel 1 memberikan gambaran karakteristik responden yaitu mahasiswa keperawatan tingkat akhir program alih jenjang.

Tabel 1. Distiribusi Frekuensi Karakteristik Mahasiswa Keperawatan Tingkat Akhir Program Alih Jenjang ( $\mathrm{n}=64)$

\begin{tabular}{|c|c|c|c|}
\hline No & Karakteristik & $\mathbf{f}$ & $\%$ \\
\hline \multirow[t]{4}{*}{1} & Umur & & \\
\hline & Masa Remaja Akhir & 38 & 59,4 \\
\hline & Masa Dewasa Awal & 15 & 23,4 \\
\hline & Masa Dewasa Akhir & 11 & 17,2 \\
\hline \multirow[t]{3}{*}{2} & Jenis Kelamin & & \\
\hline & Laki-laki & 16 & 25 \\
\hline & Perempuan & 48 & 75 \\
\hline \multirow[t]{4}{*}{3} & Status Tinggal & & \\
\hline & Rumah Sendiri & 17 & 26,6 \\
\hline & Kost & 45 & 70,3 \\
\hline & Lainnya (rumah keluarga) & 2 & 3,1 \\
\hline \multirow[t]{3}{*}{4} & Status Perkawinan & & \\
\hline & Menikah & 24 & 37,5 \\
\hline & Belum menikah & 40 & 62,5 \\
\hline \multirow[t]{10}{*}{5} & Aktifitas Selain Kuliah & & \\
\hline & Bekerja part time & 3 & 4,7 \\
\hline & Tidak bekerja & 51 & 79,7 \\
\hline & Organisasi & 0 & 0 \\
\hline & Olahraga & 0 & 0 \\
\hline & Lainnya & 0 & 0 \\
\hline & Bekerja Part Time dan Organisasi & 1 & 1,6 \\
\hline & Bekerja Part Time dan Olahraga & 1 & 1,6 \\
\hline & Tidak Bekerja dan Organisasi & 5 & 7,8 \\
\hline & Tidak Bekerja dan Olahraga & 3 & 4,7 \\
\hline \multirow[t]{3}{*}{6} & Biaya Kuliah & & \\
\hline & Mandiri/Biaya Sendiri & 39 & 60.9 \\
\hline & Beasiswa/Dibiayai & 25 & 39,1 \\
\hline \multirow[t]{5}{*}{7} & Sebagian Besar Waktu Dalam Sehari, Untuk Kegiatan & & \\
\hline & Mengerjakan Tugas Kuliah & 9 & 14,1 \\
\hline & Mengerjakan Tugas Rumah & 9 & 14,1 \\
\hline & Mengerjakan Skripsi & 46 & 71,9 \\
\hline & Lainnya & 0 & 0 \\
\hline
\end{tabular}


Tabel 1 menunjukkan bahwa lebih dari separuh mahasiswa berjenis kelamin perempuan (75\%), lebih dari separuh belum menikah (62,5\%), lebih dari separuh biaya kuliahnya mandiri/ biaya sendiri $(60,9 \%)$. Mahasiswa terbanyak adalah pada masa remaja akhir $(59,4 \%)$, tinggal di kost $(70,3 \%)$, aktifitas selain kuliah terbanyak adalah tidak bekerja $(79,7 \%)$, dan sebagian besar waktu mahasiswa dalam sehari, terbanyak digunakan untuk kegiatan mengerjakan skripsi $(71,9 \%)$.

Penelitian ini juga mendapatkan gambaran aktivitas mahasiswa dalam mengerjakan tugas akhir, seperti tampak pada tabel 2 berikut:

Tabel 2. Rerata Aktivitas Mahasiswa Keperawatan Tingkat Akhir Program Alih Jenjang dalam Mengerjakan Tugas Akhir

\begin{tabular}{clrcc}
\multicolumn{3}{c}{$(\mathrm{n}=64)$} & & \\
\hline No & Karakteristik & Mean & SD & Min - Max \\
\hline 1 & $\begin{array}{l}\text { Berapa hari dalam } \\
\text { seminggu } \\
\text { mengerjakan tugas }\end{array}$ & 5,55 & 1,447 & $3-7$
\end{tabular}

\begin{tabular}{|c|c|c|c|c|}
\hline & $\begin{array}{l}\text { akhir/ skripsi (dalam } \\
\text { hari) }\end{array}$ & & & \\
\hline 2 & $\begin{array}{l}\text { Berapa lama } \\
\text { mengerjakan skripsi } \\
\text { dalam satu hari } \\
\text { (dalam jam) }\end{array}$ & 4,28 & 1,538 & $1-9$ \\
\hline
\end{tabular}

Dari Tabel 2 dapat dilihat, rata-rata mahasiswa mengerjakan skirpsi 5,55 hari dalam seminggu dan 4,28 jam dalam sehari.

\section{Stres Akademik dan Kualitas Tidur Mahasiswa Keperawatan Tingkat Akhir Program Alih Jenjang}

Pada bagian ini akan dijelaskan hasil penelitian terkait masing-masing variabel yang diteliti. Tabel 3 memberikan data rerata stres akademik dan kualitas tidur yang dimiliki mahasiswa keperawatan tingkat akhir program alih jenjang.

Tabel 3. Rerata Stres Akademik dan Kualitas Tidur Mahasiswa Keperawatan Tingkat Akhir Progam Alih Jenjang ( $\mathrm{n}=64)$

\begin{tabular}{clcccc}
\hline No & \multicolumn{1}{c}{ Variabel } & Mean & SD & Median & Min - Max \\
\hline 1 & Stres Akademik & 147,45 & 18,768 & 149,00 & $113-191$ \\
\hline 2 & Kualitas Tidur & 11,02 & 2,925 & 12,00 & $4-16$ \\
\hline
\end{tabular}

Variabel stres akademik diukur menggunakan instrumen adalah Student Academic Stress Scale (SASS). Kuesioner SASS terdiri dari 50 pertanyaan dengan rentang penilain $50-250$, dimana nilai 50 berarti tidak mengalami stres akademik dan nilai $>50$ berarti mengalami stres akademik. Tabel 3 memberikan informasi bahwa nilai mean stres akademik mahasiswa bernilai 147,45. dimana dengan standar $\leq 50$ bermakna tidak mengalami stres akademik, dan >50 mengalami stres, ini berarti mahasiswa keperawatan tingkat akhir program alih jenjang memiliki stres akademik yang cukup tinggi.

Hasil penelitian ini sejalan dengan penelitian Devkota \& Shrestha (2018) terhadap tiga perguruan tinggi keperawatan Nepal, didapatkan hasil tingkat stres tertinggi adalah mahasiswa keperawatan tahun ke empat atau mahasiswa keperawatan tahun akhir. Kemudian menurut Reeve, Shumaker, Yearwood, Crowell, \& Riley (2013) mahasiswa keperawatan mengalami tingkat stres yang tinggi. Mahasiswa keperawatan mengalami tingkat stres yang tinggi karena tuntutan akademis dan emosional yang ketat yang diberikan pada mereka.

Mahasiswa tingkat akhir merupakan mahasiswa yang sudah melalui beberapa semester dan sedang berada pada semester akhir dengan tugas akhir yang harus diselesaikan yaitu skripsi. Menurut Iswanti (2018) pengerjaan tugas akhir/skripsi seringkali membuat mahasiswa menjadi tertekan karena beban yang cukup berat dibandingkan dengan mata kuliah yang lain.
Hasil tersebut sejalan dengan hasil penelitian dari Dhicky (2017) didapatkan bahwa tingkat stres mahasiswa yang mengerjakan skripsi di Universitas Muhammadiyah Malang, sebagian besar masuk dalam kategori sedang dengan jumlah presentase $86,5 \%$, yang berarti bahwa skripsi cukup menjadikan stresor stres terhadap mahasiswa tingkat akhir. Hasil penelitian Carsita (2018) pada mahasiswa keperawatan Sekolah Tinggi Ilmu Kesehatan Indramayu yang sedang menyelesaikan skripsi, didapatkan hasil bahwa sebanyak 28 responden (44.4\%) mengalami stress berat, 25 responden $(39,4 \%)$ mengalami stress sedang, dan 10 responden $(15,9 \%)$ mengalami stress ringan.

Bila stres akademik dilihat berdasarkan karakteristik mahasiswa program alih jenjang, stres akademik yang lebih tinggi dimiliki oleh mahasiswa yang belum menikah, sudah bekerja, berada pada usia remaja akhir, berjenis kelamin laki-laki, dan tinggal bersama keluarga/ tinggal sendiri.

Selanjutnya, kualitas tidur mahasiswa keperawatan tingkat akhir program alih jenjang diukur dengan menggunakan instrumen Pittsburg Sleep Quality Index (PSQI). Kuesioner PSQI terdiri dari 18 pertanyaan yang akan dibagi menjadi 7 komponen, kemudian dijumlahkan menjadi skor global antara 0-21. Skor global $\leq 5$ mengindikasikan kualitas tidur yang baik dan skor global $>5$ mengindikasikan kualitas tidur yang buruk. Sementara itu, pada tabel $\mathbf{3}$ dapat dilihat nilai rerata variabel kualitas tidur. Setelah sebelumnya dilakukan uji normalitas data dan ditemukan distribusi 
data pada variabel kualitas tidur tidak normal, maka digunakan nilai median.

Median variabel kualitas tidur bernilai 12 , jika skor $\leq 5$ mengindikasikan kualitas tidur yang baik, dan sebaliknya skor global $>5$ berindikasi pada kualitas tidur yang buruk, maka dapat disimpulkan kualitas tidur mahasiswa keperawatan tingkat akhir program alih jenjang memiliki kualitas tidur yang buruk.

Penelitian ini sejalan dengan penelitian yang dilakukan oleh (Zhang, Peters, \& Chen, 2018), bahwa dua pertiga dari mahasiswa keperawatan dalam penelitiannya melaporkan kualitas tidur yang buruk, yang merupakan tingkat yang lebih tinggi daripada yang dilaporkan oleh mahasiswa perguruan tinggi umum di A.S. Kemudian penelitian dari Martfandika \& Rahayu (2018) pada mahasiswa keperawatan Universitas 'Aisyiyah Yogyakarta semester delapan atau mahasiswa tingkat akhir, didapatkan kualitas tidur mahasiswa termasuk dalam kategori sangat buruk.

Hasil analisis item komponen kuesioner PSQI memberikan informasi bahwa komponen Latensi Tidur dan Disfungsi Siang Hari memiliki nilai skor tertinggi dari komponen yang lain. Menurut Purwanto (2016) latensi tidur adalah periode waktu antara persiapan untuk tidur dan awal tidur yang sebenarnya dan semakin lama latensi tidur yang diperlukan seseorang untuk tertidur maka kualitas tidur seseorang tersebut juga semakin rendah. Dengan kata lain mahasiswa keperawatan tingkat akhir program B angkatan tahun 2018 memiliki kesulitan untuk memulai tidur. Dari penelitian Yuliani, Santoso, Adi, Saraswati (2016) didapatkan mahasiswa tingkat akhir mengaku bahwa mengerjakan tugas akhir membuat jam tidur mereka lebih larut dan minim.

Penelitian yang dilakukan Raesman (2019) didapatkan pada mahasiswa tingkat akhir 58,8\% nilai komponen disfungsi siang hari yang menunjukkan bahwa mahasiswa mudah mengantuk saat beraktivitas disiang hari, kelelahan, dan kurang antusias. Sama halnya dalam penelitian ini, untuk komponen Disfungsi Siang Hari mendapatkan nilai skor yang tinggi dari komponen yang lain termasuk komponen latensi tidur. Menurut Hidayat (2006) kualitas tidur seseorang dikatakan baik jika tidak mengalami masalah dalam tidurnya dan tidak menunjukkan tanda-tanda kekurangan tidur seperti mudah lelah, gelisah, apatis, lesu, kehitaman di sekitar mata, kelopak mata bengkak, sakit kepala, sering menguap dan mudah mengantuk (dalam Sugiono, Putro, \& Sari, 2018).

Pada tabel 1 yang disajikan sebelumnya tampak bahwa aktifitas mahasiswa dalam sehari terbanyak digunakan untuk kegiatan mengerjakan tugas akhir atau skripsi $(71,9 \%)$ dan pada tabel 2 dijelaskan bahwa jumlah rata-rata jam lamanya mahasiswa mengerjakan skripsi dalam sehari adalah 4,28 jam, dengan jumlah jam yang terendah 1 jam dan yang paling lama 9 jam. Menurut penelitian Iqbal (2018) didapatkan bahwa jumlah mahasiswa dengan kualitas tidur yang tidak baik lebih banyak daripada mahasiswa dengan kualitas tidur baik, dan mahasiswa dengan kualitas tidur tidak baik lebih cenderung berpendapat bahwa tidur dapat dilakukan setelah menyelesaikan tugas.

Berdasarkan karakteristik mahasiswa, kualitas tidur yang buruk terdapat pada mereka yang belum menikah, berada pada usia remaja akhir, berjenis kelamin, laki-laki, tinggal di rumah bersama keluarga.

\section{Hubungan Stres Akademik dengan Kualitas Tidur Mahasiswa Keperawatan Tingkat Akhir Program Alih Jenjang \\ Untuk mengetahui korelasi hubungan antara} kedua variabel, dapat dilihat pada tabel 4.

Tabel 4. Hubungan Stres Akademik dengan Kualitas Tidur Mahasiswa Keperawatan Tingkat Akhir Program Alih Jenjang

\begin{tabular}{ccc}
\hline & & Kualitas Tidur \\
\hline Stres Akademik & $\mathrm{r}$ & 0,908 \\
& $p$ & 0,000 \\
& $\mathrm{n}$ & 64 \\
\hline
\end{tabular}

Uji korelasi

Spearman

Pada Tabel 4 dapat dilihat, $p$-value $<0,05$ menunjukan bahwa terdapat hubungan yang bermakna antara stres akademik dengan kualitas tidur mahasiswa keperawatan tingkat akhir program alih jenjang, dengan nilai $\mathrm{r}$ (koefisien korelasi) sebesar 0,908 yang menunjukkan bahwa arah hubungan positif dengan kekuatan hubungan sangat kuat.

Hasil penelitian ini sejalan dengan penelitian Kalyani, Jamshidi, Salami, \& Pourjam (2017), untuk penyelidikan hubungan antara variabel yang diteliti berdasarkan koefisien korelasi Pearson, ditemukan bahwa stres, kecemasan, dan depresi secara statistik terkait signifikan dengan kualitas tidur $(P<0,05)$. Begitu juga yang dijelaskan dalam Han, Kim, \& Shim (2013) pada penelitiannya yang meninjau mekanisme potensial, fisiologis, hormonal, dan neuronal yang meneliti literatur mengenai aktivitas hipotalamus-hipofisis-adrenal (HPA), salah satu sistem stres neuroendokrin utama saat tidur untuk mengidentifikasi hubungan antara stres dan tidur, dan bahwa reaksi stres didalam tubuh mengganggu fisiologis tidur.

Sementara itu, jika dilihat pada grafik dan pola hubungan yang ditampilkan pada Grafik 1 dibawah ini, terlihat titik-titik plot data membentuk pola garis lurus dari kiri bawah naik ke kanan atas. Hal ini menunjukkan bahwa ada hubungan yang linear dan positif antara variabel stres akademik (x) dengan variabel kualitas tidur (y) dan didapatkan rumus:

$y=-8,75+0,13^{*} x$.

Hubungan yang positif menjelaskan bahwa semakin besar nilai skor stres akademik yang dialami 
mahasiswa, maka semakin besar pula nilai skor kualitas tidur yang dialami mahasiswa, atau semakin tinggi stres, semakin buruk kualitas tidur.

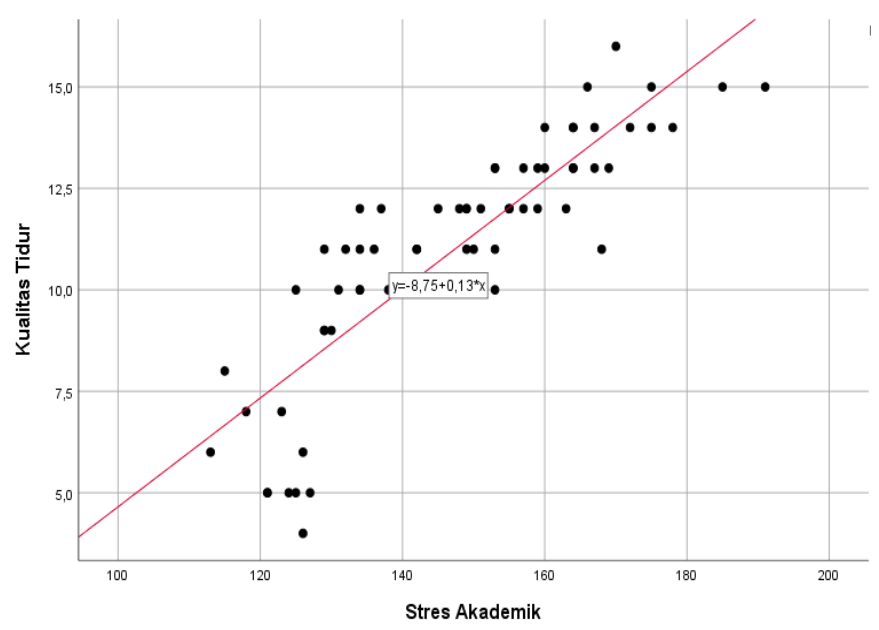

Gambar 1. Scatter Plot Hubungan Stres Akademik dengan Kualitas Tidur Mahasiswa Keperawatan Tingkat Akhir Program Alih Jenjang

Menurut Marks \& Landaira (2016), jika stres yang berlebihan atau berkepanjangan dan intens, atau jika kita tidak tahu bagaimana berurusan dengan mereka, mereka dapat mengakibatkan masalah kesehatan besar fisiologis dan psikologis. Ini termasuk depresi, sulit tidur, insomnia atau penyesuaian negatif lainnya. Ini adalah karena bagaimana seseorang menangani stres pada gilirannya akan mempengaruhi bagaimana mereka tidur.

Menurut Silva, Chaves, Duarte, Amaral, \& Ferreira (2016) tidur harus menjadi perhatian utama untuk kinerja akademik. Melatih siswa keperawatan tentang kualitas tidur adalah hal mendasar berkontribusi tidak hanya pada pengambilan keputusan di tingkat individu, tetapi juga agar sebagai profesional kesehatan, mereka sebagai perantara informasi dan mendorong kebiasaan hidup sehat.

Dari hasil penelitian ini menjelaskan bahwa stres akademik yang dirasakan mahasiswa mempengaruhi atau membuat kualitas tidur yang buruk pada mahasiswa. Oleh karna itu mengurangi stres akademik mahasiswa adalah salah satu cara untuk memperbaiki kualitas tidur mahasiswa. Untuk mengurangi stres mahasiswa bisa dengan cara Manajemen Stres.

Sebuah penelitian dilakukan oleh Hakim, Tantiani, Shanti (2017) tentang Efektifitas Pelatihan Manajemen Stres Pada Mahasiswa dengan subyek penelitian sebanyak 80 mahasiswa yang berasal dari berbagai fakultas di Universitas Negeri Malang. Mereka diukur saat pre test, diberi perlakuan, kemudian diberi post test. Responden diberikan materi tentang stres serta simulasi dengan melakukan role play dan teknik relaksasi. Setelah itu dilakukan analisis paired sample ttest dan didapatkan nilai signifikansi $0,000<$ <alpha $(0,05)$. Hasil penelitian ini menunjukkan bahwa pelatihan manajemen stress ini tergolong efektif bagi mahasiswa.

\section{SIMPULAN}

Berdasarkan penelitian yang sudah dilakukan, didapatkan simpulan bahwa terdapat mahasiswa keperawatan tingkat akhir program alih jenjang di tempat penelitian memiliki stres akademik yang tinggi dan kualitas tidur yang buruk. Terdapat hubungan yang bermakna antara stres akademik dengan kualitas tidur mahasiswa keperawatan tingkat akhir program alih jenjang, dengan arah hubungan positif dan kekuatan hubungan sangat kuat.

Diharapkan mahasiswa keperawatan tingkat akhir program alih jenjang dapat mengatur penjadwalan tidur yang baik dan pengaturan kegiatan terkait perkuliahan atau kegiatan yang lain, agar mahasiswa memperoleh kualitas tidur yang baik. Mahasiswa juga diharapkan dapat mengenal faktor-faktor gangguan tidur yang dialami terkait dengan kualitas tidur yang buruk, salah satunya dalam penelitian ini adalah stres akademik. Pemahaman tentang manajemen stres sangat diperlukan mahasiswa dalam mengelola stres akademik. Dengan memahami dan menguasai manajemen stres, dapat mengurangi stres akademik dan dapat memperbaiki kualitas tidur mahasiswa sehingga akhirnya tidak mengganggu kesehatan mahasiswa secara umum, dan juga prestasi akademik mahasiswa.

\section{DAFTAR PUSTAKA}

Almojali, A. I., Almalki, S. A., Alothman, A. S., Masuadi, E. M., \& Alaqeel, M. K. (2017). The prevalence and association of stress with sleep quality among medical students. Journal of Epidemiology and Global Health, 7(3), 169-174. https://doi.org/10.1016/j.jegh.2017.04.005

Becker, N. B., Jesus, S. N., Marguilho, R., Viseu, J., Rio, K. A., \& Buela, C. G. (2015). Sleep quality and stress : a literature review. Advanced Research in Health, Education and Social Sciences: Towards a Better Practice, (April 2016), 53-61.

Carsita, W. N. (2018). Tingkat Stres Pada Mahasiswa Keperawatan Yang Menyusun Skripsi. Journal of Nurs, 6(9), 1689-1699. https://doi.org/10.1017/CBO9781107415324.004

Devkota, R., \& Shrestha, S. (2018). Stress among Bachelor Level Nursing Students. Department of Nursing, Nepal Medical College Journal, 20(1-3), $33-40$.

Dhicky, Z. (2017). Tingkat Stres Mahasiswa Ketika Menempuh Skripsi. Skipsi, Malang. Universitas Muhammadiyah Malang.

Fenny, \& Supriatmo. (2016). Hubungan Kualitas Dan Kuantitas Tidur Dengan Prestasi Belajar Pada Mahasiswa Fakultas Kedokteran Universitas Sumatra Utara. Jurnal Kedokteran, 5(3), 140-147. García-Ros, R., Pérez-González, F., \& Tomás, J. M. 
(2018). Development and validation of the questionnaire of academic stress in secondary education: Structure, reliability and nomological validity. International Journal of Environmental Research and Public Health, 15(9).

https://doi.org/10.3390/ijerph15092023

Giese, M., Unternaehrer, E., Brand, S., Calabrese, P., Holsboer-Trachsler, E., \& Eckert, A. (2013). The Interplay of Stress and Sleep Impacts BDNF Level. $\quad P L O S \quad O N E, \quad 8(10)$. https://doi.org/10.1371/journal.pone.0076050

Hakim, G. R. U., Tantiani, F. F., \& Shanti, P. (2017). Efektifitas Pelatihan Manajemen Stres Pada Mahasiswa. Jurnal Sains Psikologi, 6, No 2(November), $\quad$ 75-79. http://dx.doi.org/10.17977/um023v6i22017p076

Hallet, K., Chernaik, M., \& Zhang, Y. (2017). Relationship Issues Among College Nursing Students: Associations With Stress, Coping, Sleep, and Mental Disorders. Teaching and Learning in Nursing, 12(4), 246-252. https://doi.org/10.1016/j.teln.2017.06.005

Han, K. S., Kim, L., \& Shim, I. (2013). Stress and Sleep Disorder. Experimental Neurobiology, 21(4), 141. pISSN 1226-2560. eISSN 2093-8144. https://doi.org/10.5607/en.2012.21.4.141

Hill, V. M., O’Connor, R. M., Sissoko, G. B., Irobunda, I. S., Leong, S., Canman, J. C., Shirasu-Hiza, M. (2018). A bidirectional relationship between sleep and oxidative stress in Drosophila. PLoS Biology, 16(7), $1-22$. https://doi.org/10.1371/journal.pbio.2005206

Iswanti, S. (2018). Alat Bantu Pengidentifikasi Tingkat Stres Mahasiswa Yang Sedang Mengerjakan Tugas Akhir/skripsi. Informatika Upgris, 4(1), 56-63.

https://doi.org/http://dx.doi.org/10.26877/jiu.v4i1. 2311. P/E-ISSN: 2460-4801/2447-6645.

Kalyani, M. N., Jamshidi, N., Salami, J., \& Pourjam, E. (2017). Investigation of the Relationship between Psychological Variables and Sleep Quality in Students of Medical Sciences. Depression Research and Treatment, 2017. https://doi.org/10.1155/2017/7143547

Nedeltcheva, A. V., \& Scheer, F. A. J. L. (2014). Metabolic effects of sleep disruption, links to obesity and diabetes. Current Opinion in Endocrinology, Diabetes and Obesity, 21(4), 293298.

https://doi.org/10.1097/MED.0000000000000082

Perumal, S. R. P., Narasimhan, M. and Kramer, M. (2016). Sleep and Psychosomatic Medicine, New York, CRC Press.

Potter, P. A. \& Perry, A. G. (2006). Buku Ajar Fundamental Keperawatan: Konsep, Proses, Dan Praktik. Jakarta: EGC.
Purwanto, S. (2016). Hubungan antara Intensitas Menjalankan Dzikir Nafas dengan Latensi Tidur. Indigenous: Jurnal Ilmiah Psikologi, 1(1), 32. ISSN: 0854-2880. https://doi.org/10.23917/indigenous.v1i1.3713

Raesman, S. (2019). Perbandingan Stres Akademik Dan Kualitas Tidur Mahasiswa Program A Fakultas Keperawatan Universitas Andalas Pada Mahasiswa Tahun 2018, 2017, 2016, dan 2015. Skripsi, Padang. Fakultas Keperawatan Universitas Andalas.

Rahmawati, F., \& Kuntari. (2014). Kualitas Tidur Dan Minat Belajar Mahasiswa Program Studi Sarjana Kelas Ekstensi Fakultas Ilmu Keperawatan Universitas Indonesia. Jurnal Keperawatan. 1-8.

Silva, M., Chaves, C., Duarte, J., Amaral, O., \& Ferreira, M. (2016). Sleep Quality Determinants among Nursing Students. Procedia - Social and Behavioral Sciences, 217, 999-1007. https://doi.org/10.1016/j.sbspro.2016.02.090

Sosso, F. A. E., Nakamura, O., \& Nakamura, M. (2017). Evaluation of Combined Effects of Insomnia and Stress on Sleep Quality and Sleep Duration. Journal of Neurology and Neuroscience, 08(03), 1-5. https://doi.org/10.21767/21716625.1000202

Sugiono, Putro, W. W., \& Sari, S. I. K. (2018). Ergonomi Untuk Pemula: Prinsip Dasar Dan Aplikasinya. Malang: UB Pres.

Yikealo, D., Yemane, B., \& Karvinen, I. (2018). The Level of Academic and Environmental Stress among College Students: A Case in the College of Education. Open Journal of Social Sciences, 06(11), 40-57. https://doi.org/10.4236/jss.2018.611004

Yuliani, H., Santoso, H. S., Adi, M. S., \& Saraswati, L. D. (2016). Gambaran Faktor Risiko Aktivitas Fisik, Kualitas Tidur, Dan Stres Dengan Tekanan Darah Pada Mahasiswa Tingkat Akhir Fakultas Teknik Universitas Diponegoro. Jurnal Kesehatan Masyarakat Universitas Diponegoro, 4(4), 387393.ISSN: $2356-3346$.

Zhang, Y., Peters, A., \& Chen, G. (2018). Perceived Stress Mediates the Associations between Sleep Quality and Symptoms of Anxiety and Depression among College Nursing Students. International Journal of Nursing Education Scholarship. 1-9. https://doi.org/10.1515/ijnes-2017-0020 